\title{
Purification of Cytochrome $a$ of an L-Glutamate-producing Microorganism, Brevibacterium thiogenitalis ${ }^{\dagger}$
}

\author{
Yoshio SugrYama, Kazuaki KITANO* and Toshihiko KanZAKI* \\ Takasago Plant, Takeda Chemical Industries, Ltd., Takasago, Hyogo, Japan \\ Received December 4, 1972
}

\begin{abstract}
The respiratory chain system of Brev. thiogenitalis grown in the presence of copper ions contained cytochromes $a, b$ and $c$. The cytochrome $a$ was solubilized and purified from the cell-free extracts by means of Triton X-100 and cholate extraction, and DEAE-cellulose chromatography. It was purified about 130 -fold from the cell-free extracts and was free from other cytochromes. The purified preparation contained $1.4 \mathrm{~m} \mu$ atom copper and $1.9 \mathrm{~m} \mu$ atom iron per $\mathrm{m} u$ mole heme $a$, respectively, and approximately $5 \mathrm{~m} \mu$ moles heme $a$ per mg protein.
\end{abstract}

It has been well established that cytochrome $a$ of mammals and yeasts contains copper as well as iron. ${ }^{1 \sim 6)}$ Moreover, many investigators $^{7 \sim 9)}$ observed that a specific deficiency of cytochrome $a$ and a conspicuous decrease in cytochrome oxidase activity in rat liver were caused by a copper deficient diet. On the other hand, little is known about bacterial cytochrome $a$. No cytochrome $a$ has yet been solubilized and purified from bacterial sources, so all data available have been obtained spectrophotometrically using whole cell suspensions or membrane fragments. ${ }^{10 \sim 12}$

In the previous paper, ${ }^{13)}$ the authors demonstrated that the formation of L-glutamate from acetate by L-glutamate-producing bacteria was markedly enhanced by the presence of copper ions in growth media. It was also noticed that succinic oxidase activity of copper sufficient cells was higher than that of deficient cells, which suggested a close relationship between copper and respiratory activity. The above and some other findings led us to study the respiratory chain of the bacteria.

This paper describes the procedure used for the purification of cytochrome $a$ from

$\dagger$ This work was presented at the Annual Meeting of the Agricultural Chemical Society of Japan, held in Sendai, April, 1972.

* Microbiological Research Laboratories, Central Research Division, Takeda Chemical Industries, Ltd., Osaka, Japan. cell-free extracts and the occurrence of copper in the purified preparation.

\section{MATERIALS AND METHODS}

Organism and culture conditions. Brevibacterium thiogenitalis D-248 (an oleic acid-requiring mutant) was used. The composition of media and culture conditions were the same as in the fermentation with acetate described previously. ${ }^{131}$ Copper ions were added as $\mathrm{CuSO}_{4} \cdot 5 \mathrm{H}_{2} \mathrm{O}(0.125 \mu \mathrm{g}$ per $\mathrm{ml})$ in the main medium (acetate medium).

Analyses. Measurement of absorption spectra was performed by a Hitachi-Perkin Elmer spectrophotometer model 124, fitted with a Hitachi recorder QPD-34, using a cuvette of 1-cm light path. The concentrations of cytochromes, $a, b$ and $c$ in crude preparations were determined by the use of the difference extinction coefficients of $11.9,{ }^{1 /} 14.4^{14}$ and $21.0 \mathrm{~mm}^{-1} \mathrm{~cm}^{-1151}$ at the alpha peaks in reduced minus oxidized spectra, respectively. The concentration of cytochrome $a$ in purified preparations was calculated by using the difference extinction coefficient of $16.5 \mathrm{~mm}^{-1} \mathrm{~cm}^{-11}$ between 601 and $630 \mathrm{~m} \mu$ in the reduced state.

Total iron and copper concentrations were determined according to the method of Yonetani. ${ }^{3 /}$ Disc electrophoresis was performed by the method according to Ornstein ${ }^{17)}$ and Davis. ${ }^{18}$ Protein concentration was determined according to the method of Lowry et al. ${ }^{16 !}$

Purification of cytochrome a from cell-free extracts. All the following treatments were performed at $0 \sim 4^{\circ} \mathrm{C}$. The cells were harvested at a late logarithmic growth phase by centrifugation and washed twice with $0.1 \mathrm{M}$ 
potassium phosphate buffer ( $\mathrm{pH} 7.5$ ). Wet cells $(100 \mathrm{~g})$ were suspended in 1 liter of the above buffer and disrupted by a Kubota $10 \mathrm{kc}$ sonic oscillator model $200 \mathrm{M}$ at $160 \mathrm{~W}$ output for $30 \mathrm{~min}$ in $50 \mathrm{ml}$ each batch. Triton $\mathrm{X}-100(20 \mathrm{ml})$ was added to the solution, followed by stirring overnight. The solution was centrifuged at $10,000 \times \mathrm{g}$ for $30 \mathrm{~min}$. To the supernatant solution $(940 \mathrm{ml})$, solid ammonium sulfate was slowly added to $30 \%$ saturation, and the mixture was stirred for $1 \mathrm{hr}$, followed by centrifugation at $10,000 \times g$ for $10 \mathrm{~min}$. A yellow layer which appeared on the top was carefully removed. To the lower clear brown layer, solid ammonium sulfate was further added to give $60 \%$ saturation. After standing for $2 \mathrm{hr}$, the solution was centrifuged at $10,000 \times g$ for $10 \mathrm{~min}$. The precipitate was collected and dissolved in $200 \mathrm{ml}$ of the buffer described above. After removal of insoluble materials by centrifugation, the solution was supplemented with sodium cholate to give a concentration of $0.5 \%(\mathrm{w} / \mathrm{v})$ and then ammonium sulfate was added to $20 \%$ saturation. The mixture was stirred overnight and centrifuged. To the supernatant solution ammonium sulfate was added to $30 \%$ saturation and the mixture was stirred for $2 \mathrm{hr}$. The solution was centrifuged at $10,000 \mathrm{~g} g$ for $10 \mathrm{~min}$. The resulting gelatinous sediment was collected and dissolved in $30 \mathrm{ml}$ of $0.01 \mathrm{M}$ Tris- $\mathrm{HCl}$ buffer $(\mathrm{pH} 8.0)$ containing Triton $\mathrm{X}-100(0.5 \mathrm{w} / \mathrm{v} \%)$, followed by dialysis against the same buffer. The dialyzed solution was applied to a DEAE-cellulose column $(3 \% 50 \mathrm{~cm})$, previously equilibrated with the above buffer. A linear gradient elution was performed by a two chamber system with $0.2 \mathrm{M}$ Tris- $\mathrm{HCl}$ buffer $(\mathrm{pH} \mathrm{8.0)}$ containing Triton $\mathrm{X}-100$ in the first chamber and $2 \mathrm{M}$ Tris- $\mathrm{HCl}$ buffer ( $\mathrm{pH} \mathrm{8.0)} \mathrm{containing} \mathrm{Triton} \mathrm{X}-100$ in the second one and at a flow rate of $c a .30 \mathrm{ml}$ per $\mathrm{hr}$. Fractions (ten $\mathrm{ml}$ each) from tube No. 12 to 32 were combined. To $210 \mathrm{ml}$ of the pooled fraction which contained cytochromes $a$ and $c$, solid ammonium sulfate was slowly added to $50 \%$ saturation. By centrifugation, the upper fluffy layer was carefully collected, dissolved in a small amount of $0.01 \mathrm{M}$ Tris$\mathrm{HCl}$ buffer and dialyzed. The dialyzed solution was subjected to the second DEAE-cellulose chromatography as described above. To the greenish eluate (tube No. 18 to 23) which contained cytochrome $a$ was added solid ammonium sulfate to give $50 \%$ saturation. The upper fluff was collected by centrifugation and dissolved in $10 \mathrm{ml}$ of $0.05 \mathrm{M}$ Tris- $\mathrm{HCl}$ buffer ( $\mathrm{pH} 7.5$ ) containing Triton $X-100(0.5 \%)$. The clear greenish solution was applied on a Sephadex G-200 column $(3 \times 40 \mathrm{~cm})$, previously equilibrated with the above buffer. Cytochrome $a$ solution thus obtained was used for further analyses.

Chemicals. Sodium cholate was purchased from Sigma Chemical Co., and used without further puri- fication. Triton $\mathrm{X}-100$ was obtained from Wako Chemical Co., Tokyo. Other chemicals were of the purest grade commercially available.

\section{RESULTS}

\section{Respiratory components}

The dithionite reduced minus air oxidized difference spectra of the cell-free extracts of Brev. thiogenitalis grown in the presence or absence of copper ions are shown in Fig. 1. Cell-free extracts of the copper sufficient cells revealed absorption peaks at $602,563,552 \mathrm{~m} \mu$ which represent the alpha peak of cytochromes $a, b$ and $c$, respectively (A), while those of the copper deficient cells revealed absorption peaks at 563 and $630 \mathrm{~m} \mu$ indicating the alpha peak of cytochromes $b$ and $d$, respectively (B).

As shown in Fig. 2, cytochrome $a$ content in the cell-free extracts was proportional to the concentration of copper ions in the growth medium up to $25 \mu \mathrm{g}$ per litre. Thus Brevibacterium cytochrome $a$ was expected to be a copper protein like cytochrome $a$ of mammals and yeasts.

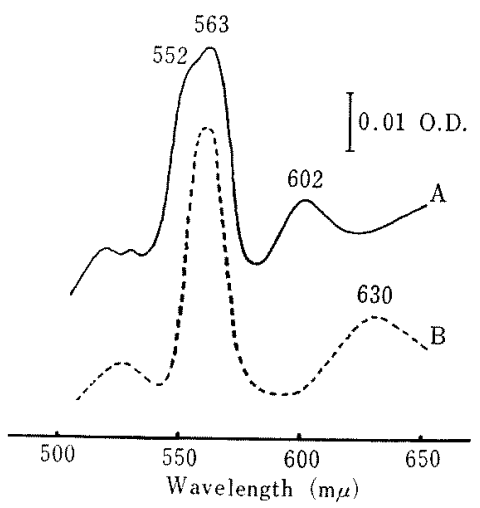

Frg. 1. Difference Spectra of Brev. thiogenitalis Cell-free Extracts.

Cell-free extracts in the cuvette were reduced with dithionite, while those in the reference cuvette were kept under an aerobic condition. The reaction mixture contained $45 \mathrm{mg}$ of protein, $300 \mu$ moles of potassium phosphate buffer $(\mathrm{pH} 7.5)$ and distilled water to $3.0 \mathrm{ml}$.

A: Spectrum of cell-free extracts of copper sufficient cells which were grown in the acetate medium containing $0.025 \mu \mathrm{g}$ per $\mathrm{ml}$ of copper ions.

B: Spectrum of cell-free extracts of copper deficient cells which were grown in the acetate medium without added copper ions. 


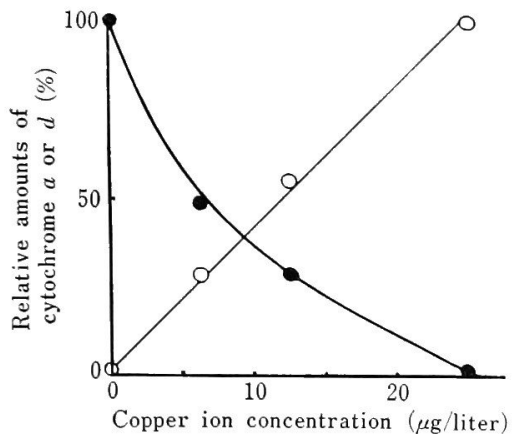

FIG. 2. Effect of Copper Ion Concentrations in the Acetate Medium on the Contents of Cytochromes $a$ and $d$.

The relative amounts of cytochromes $a(O)$ and $d$ $(\bullet)$ were expressed as per cent of the content in cellfree extracts of copper sufficient cells and in those of copper deficient cells, respectively.

\section{Purification}

Table I shows a typical example of the results on purification of cytochrome $a$ of the cell-free extracts. The results indicate that only $6 \%$ of the cytochrome $a$ in the cellfree extracts were recovered in the purified preparation. However, cytochrome $a$ was purified to 133 -fold relative to the protein content. The content of cytochrome $a$ in the final preparation was approximately $5 \mathrm{~m} \mu$ moles per $\mathrm{mg}$ protein, which was somewhat lower than that of animal heart or yeast preparation. ${ }^{6,19)}$

The purified preparation was subjected to disc electrophoresis in polyacrylamide gel at $\mathrm{pH} 8.8$ in $375 \mathrm{~mm}$ Tris- $\mathrm{HCl}$ buffer with a

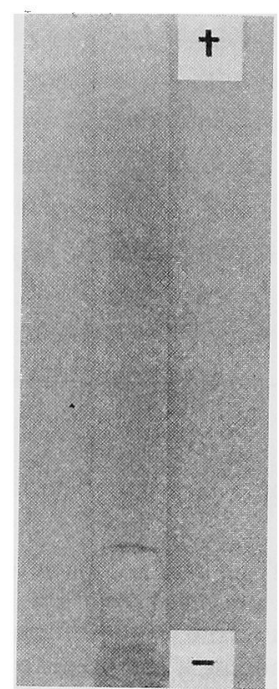

FIG. 3. Disc Gel Electrophoresis of Purified Cytochrome $a$ Preparation.

A disc electrophoretic pattern of the purified cytochrome $a$ preparation in polyacrylamide gel $(7 \%)$ at $\mathrm{pH}$ 8.8. Protein was stained with amido black.

current of $4 \mathrm{~mA}$ per tube $(0.5 \times 8 \mathrm{~cm})$. As shown in Fig. 3, it showed a single band when stained with amido black.

\section{Absorption spectrum}

The final preparation of cytochrome $a$ was a completely clear solution, but when concentrated several times after dialysis against deionized water, the solution got turbid. Therefore, the spectrum was observed in the presence of a synthetic nonionic detergent, Triton X-100 (final concentration $0.5 \%$ ). As

Table I. Summary of Purification of Cytochrome $A$ from Brev. thiogenitalis

\begin{tabular}{lccccc}
\hline \multicolumn{1}{c}{ Fraction } & $\begin{array}{c}\text { Volume } \\
(\mathrm{ml})\end{array}$ & $\begin{array}{c}\text { Total } \\
\text { protein } \\
(\mathrm{mg})\end{array}$ & $\begin{array}{c}\left.\text { Cyt. } a^{b}\right) \\
(\mathrm{m} \mu \text { moles })\end{array}$ & $\begin{array}{c}\text { Yield } \\
(\%)\end{array}$ & $\begin{array}{c}\text { Cyt.a } \\
(\mathrm{m} \mu \mathrm{moles}) \\
\text { per mg } \\
\text { protein }\end{array}$ \\
\hline Triton extract & 940 & 12088 & 471 & 100 & 0.039 \\
Ammonium sulfate 30 $60 \%$ sat. & 200 & 5641 & 425 & 90 & 0.075 \\
Cholate extract & 30 & 1047 & 282 & 60 & 0.269 \\
1st. DEAE-cellulose eluate & 210 & 108 & 145 & 31 & 1.34 \\
2nd. DEAE-cellulose eluate & 60 & 7.9 & 40 & 8 & 5.06 \\
Purified cyt. $a$ & 28 & 5.6 & 29 & 6 & 5.18
\end{tabular}

a) Protein was determined by the method of Lowry et al. ${ }^{16)}$

b) The content of cytochrome $a$ was determined based on the difference extinction coefficient of $11.9 \mathrm{~mm}^{-1}$ $\mathrm{cm}^{-1}$ at the alpha peak in reduced minus oxidized spectrum. 


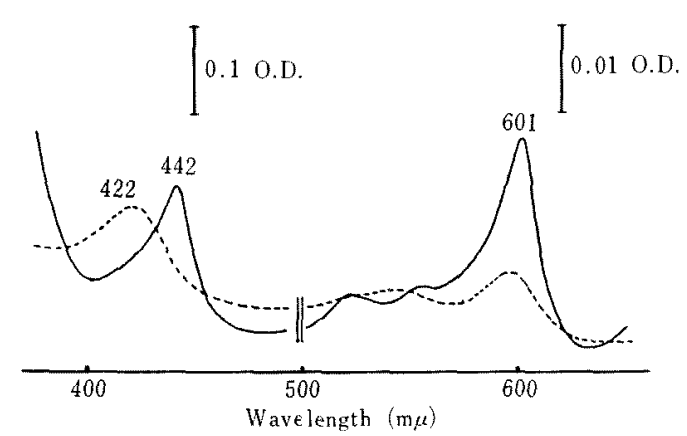

FIG. 4. Absorption Spectra of Purified Cytochrome a.

The spectrum of the oxidized form (dotted line) was obtained in the presence of $10 \mu \mathrm{M}$ potassium ferricyanide and that of the reduced form (solid line) was measured after adding a few grains of sodium dithionite. The reaction mixture in a total volume of $3.0 \mathrm{ml}$ contained approximately $1.2 \mathrm{mg}$ of protein, $15 \mu$ moles of Tris- $\mathrm{HCl}$ buffer (pH 7.5) and $15 \mathrm{mg}$ of Triton $\mathrm{X}-100$.

can be seen in Fig. 4, the spectra show that the main component of the preparation was cytochrome $a$. On addition of a trace amount of sodium dithionite, the completely reduced

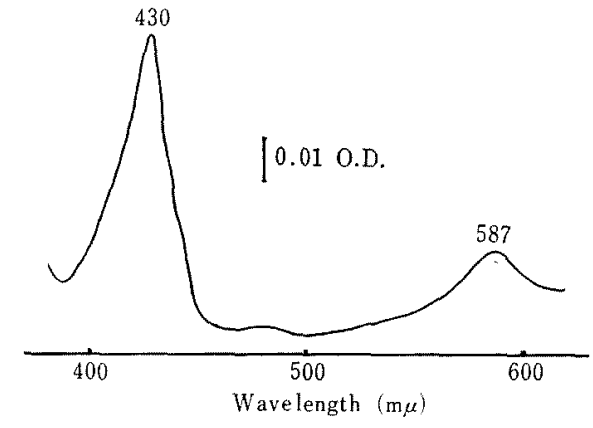

FIG. 5. Absorption Spectrum of Pyridineferrohemochrome of Purified Cytochrome $a$.

For the method of preparation, see text.

form was obtained, which showed absorption maxima at 601,520 and $442 \mathrm{~m} \mu$. The oxidized form, obtained after the addition of $10 \mu \mathrm{M}$ ferricyanide, showed absorption peaks at 597 and $422 \mathrm{~m} \mu$.

\section{Prosthetic group}

The heme was extracted with acid-acetone solution ( $1 \mathrm{ml}$ conc. $\mathrm{HCl}$ in $100 \mathrm{ml}$ acetone), concentrated almost to dryness and trans-

Table II. Copper and Iron Contents of Purified Cytochrome $A$

\begin{tabular}{|c|c|c|c|c|c|}
\hline $\begin{array}{c}\text { Preparation } \\
\text { No. }\end{array}$ & $\begin{array}{c}\text { Cyt. } a^{a)} \\
\text { (mumoles) }\end{array}$ & $\begin{array}{c}\mathrm{Cu}^{b} \\
(\mathrm{~m} \mu \text { moles })\end{array}$ & $\begin{array}{c}\mathrm{Fe}^{c)} \\
(\mathrm{m} / \mathrm{moles})\end{array}$ & $\frac{\mathrm{Cu}}{\text { Heme } a}$ & $\frac{\mathrm{Cu}}{\mathrm{Fe}}$ \\
\hline 1 & 30.3 & 45.0 & 63.7 & 1.5 & 0.71 \\
\hline 2 & 27.0 & 34.0 & 83.0 & 1.3 & 0.41 \\
\hline 3 & 35.2 & 45.0 & 88.0 & 1.3 & 0.51 \\
\hline Average & & & & 1.4 & 0.54 \\
\hline
\end{tabular}

a) The content of cytochrome $a$ was calculated by using the difference extinction coefficient of $16.5 \mathrm{~mm}^{-1}$ $\mathrm{cm}^{-1}$ between 601 and $630 \mathrm{~m} \mu$ in the reduced state.

b) Copper content was determined with the zinc dibenzyldithiocarbamate method after digestion with conc. $\mathrm{H}_{2} \mathrm{SO}_{4}$.

c) Iron content was determined with the $o$-phenanthroline method.

Table III. Relation between Copper and Cytochrome $A$ Contents during the Purification Process

Before analyses each fraction was subjected to gel filtration on Sephadex G-200 in order to remove contaminated copper and iron ions.

\begin{tabular}{|c|c|c|c|c|c|c|c|c|}
\hline \multirow{2}{*}{ Fraction } & \multicolumn{4}{|c|}{ Cytochrome (m $\mu$ moles) } & \multirow{2}{*}{$\begin{array}{c}\mathrm{Cu} \\
(\mathrm{m} \mu \mathrm{moles})\end{array}$} & \multirow{2}{*}{$\begin{array}{c}\mathrm{Fe} \\
\text { (m } \mu \text { moles) }\end{array}$} & \multirow{2}{*}{$\frac{\mathrm{Cu}}{\text { Heme } a}$} & \multirow{2}{*}{$\begin{array}{c}\mathrm{Fe} \\
\text { Total } \\
\text { heme }\end{array}$} \\
\hline & $a$ & $b$ & $c$ & Total & & & & \\
\hline Cholate extract & 32.8 & 48.2 & 35.3 & 116.3 & 56.3 & 309.0 & 1.7 & 2.7 \\
\hline $\begin{array}{l}\text { 1st. EDAE-cellulose } \\
\text { eluate }\end{array}$ & 24.6 & trace & 6.6 & 31.2 & 35.0 & 85.0 & 1.4 & 2.7 \\
\hline Purified cyt. $a$ & 30.0 & 0 & 0 & 30.3 & 45.0 & 63.7 & 1.5 & 2.1 \\
\hline
\end{tabular}


ferred to pyridine. It was reduced with a trace amount of sodium dithionite after adjusting the $\mathrm{pH}$ to 10 . In this way, a clear absorption spectrum of the pyridineferrohemochrome was obtained as shown in Fig. 5. These results indicate that cytochrome $a$ purified from Brev. thiogenitalis contained heme a as its prosthetic group.

\section{Copper and iron contents}

Copper and iron contents in the purified preparations are shown in Table II. Assuming that the molar extinction coefficient of Brevibacterium cytochrome $a$ is identical to that of the beaf heart cytochrome $a$, the ratio ( $\mathrm{m} \mu$ atoms per m $\mu$ mole) of copper to heme $a$ was 1.4. The atomic ratio of copper to iron was calculated to be approximately 0.54 . The extinction coefficient of Brevibacterium cytochrome $a$ based on the total copper was calculated to be approximately $11.8 \mathrm{~mm}^{-1} \mathrm{~cm}^{-1}$ which was a considerably lower value than that given for the beaf heart muscle preparation $\left(16.5 \mathrm{mM}^{-1} \mathrm{~cm}^{-1}\right)$. ${ }^{1}$

The behavior of cytochrome $a$ and copper during the purification process is also presented in Table III. As can be seen in Table III, one mole of cytochrome a contained at least one atom of copper at all the purification stages.

\section{DISCUSSION}

Bacterial cytochrome $a$ can be classified into two groups; one shows the reduced alpha and gamma peaks at $585 \sim 595 \mathrm{~m} \mu$ and $435 \sim$ $445 \mathrm{~m} \mu$, respectively, and the other those at $600 \sim 605 \mathrm{~m} \mu$ and $440 \sim 445 \mathrm{~m} \mu$, respectively, similar to mammalian cytochrome $a$. The former has been termed cytochrome $a_{1}$. The latter has been represented by the term, cytochromes $a$ and $a_{3}$, analogous to mammalian cytochrome $\left(a a_{3}\right)$, if the spectrochemical responses of the alpha and gamma peaks toward carbon monooxide and cyanide are similar to those of mammalian cytochrome $\left(a a_{3}\right)$. In the presence of carbon monooxide, the alpha peak around $605 \mathrm{~m} \mu$ and the gamma peak around $445 \mathrm{~m} \mu$ of reduced cytochrome $a_{3}$ shift to approximately $590 \mathrm{~m} \mu$ and $430 \mathrm{~m} \mu$, respectively, but those of reduced cytochrome $a$ are not affected. From the spectrophotometric observations, it is known that various bacteria possess cytochrome $a$ of the latter type. Such examples are Mycobacterium phlei ${ }^{20)}$ Bacillus subtilis, ${ }^{213}$ Micrococcus lysodeikticus, $^{22)}$ aerobically grown Rhodopseudomonas spheroides, ${ }^{23)}$ etc. An exception was found in Staphylococcus albus (Micrococcus pyogenes var. albus $\left.{ }^{24}\right)$ which showed reduced bands at 604,565 and $552 \mathrm{~m} \mu$. The absorption spectrum of the cytochrome $a$ was not affected by carbon monooxide. Thus, this cytochrome has been classified as cytochrome a. A study of the aerobic Bacillus subtilis afforded the first example of a chemical characterization of the presence of cytochrome $a$ by demonstration of extractability of a heme $a$ from respiratory particles using acid-acetone. ${ }^{25}$ ) In this case, however, the cytochrome $a$ was identified only as cytochrome $a_{601}$, with no specific comparison with the mitochondrial $a a_{3}$.

Brevibacterium cytochrome $a$ described here was regarded as cytochrome $a$ (perhaps $a$ and $a_{3}$ ) by the following criteria, (1) it showed the reduced alpha and gamma bands at $601 \mathrm{~m} \mu$ and $442 \mathrm{~m} \mu,(2)$ heme $a$ was removable from the apoprotein by extraction with acid-acetone, (3) the pyridine ferrohemochrome in alkali showed an alpha band at $587 \mathrm{~m} \mu$, and (4) the cytochrome $a$ contained at least an equimolar amount of copper to heme $a$. The last finding is noteworthy, not only because it is the first demonstration of the occurrence of copper in bacterial cytochrome $a$ ( $a$ and $a_{3}$ ) so far reviewed, but also because it suggests the universality of the role of copper in cytochrome $a$ ( $a$ and $a_{3}$ ).

The details of the relation between copper and the respiratory chain system will be discussed in the following paper.

Acknowledgements. The authors wish to thank to Messrs. T. Terada, K. Takeba, Y. Tokuda and I. Nakanishi, Takasago Plant of Takeda Chemical Industries, Ltd. for continued interest and encouragement throughout the course of this work and to Dr. 
M. Isono for his critical reading of this paper. Thanks are also due to Mr. K. Minami for his technical assistance.

\section{REFERENCES}

1) H. Matsubara, Y. Orii and K. Okunuki, Biochem. Biophys. Acta, 97, 61 (1965).

2) Y. Orii and K. Okunuki, J. Biochem., 61, 388 (1967).

3) T. Yonetani, J. Biol. Chem., 236, 1680 (1961).

4) D. E. Griffiths and D. C. Wharton, ibid., 236, 1850 (1961).

5) S. Horie and M. Morrison, ibid., 238, 1855 (1963).

6) I. Sekuzu, H. Mizushima, S. Hirota, T. Yubisui, Y. Matsumura and K. Okunuki, J. Biochem., 62, 710 (1967).

7) E. Cohen and C. A. Elvehjem, J. Biol. Chem., 107, 97 (1934).

8) H. Yoshikawa, J. Biochem., 25, 627 (1937).

9) C. H. Gallagher, J. H. Judah and K. R. Ress, Proc. Roy. Soc., London. B 145, 134 (1956).

10) L. Smith, Bacteriol. Rev., 18, 106 (1954).

11) L. Smith, "The Bacteria," Vol. II, ed. by G. Gunsalus and R. Y. Stainer, Academic Press Inc., New York, N.Y., 1961, p 572.

12) L. Smith, N. Newton and P. Scholes, "Hemes and Hemoproteins," ed. by B. Chance, R. Estabrook and T. Yonetani, Academic Press
Inc., New York, N.Y., 1966, p. 395.

13) T. Kanzaki, I. Nakatsui, K.Kitano, Y. Sugiyama, M. Nishio and M. Ishikawa Agr. Biol. Chem., in press.

14) K. Ohnish, J. Biochem., 59, 17 (1966).

15) B. F. van Gelder and E. C. Slater, Biochem. Biophys. Acta, 58, 593 (1962).

16) O. H. Lowry, N. J. Rosebrough, A. L. Farr and R. J. Randall, J. Biol. Chem., 193, 265 (1951).

17) L. Ornstein, Ann. New York Acad. Sci., 121, Art 2, 321 (1964).

18) B. J. Davis, ibid., 121, Art 2, 404 (1964).

19) T. Yubisui, Ann. Rep. Biol. Works, Fac. Sci., Osaka Univ., 16, 35 (1962).

20) A. Asano and A. F. Brodie, J. Biol. Chem., 239, 4280 (1965).

21) K. Miki and K. Okunuki, J. Biochem., 66, 831, 845 (1969).

22) S. Ishikawa and A. L. Lehninger, $J$. Biol. Chem., 237, 2401 (1962).

23) G. Kikuchi and Y. Motokawa, "Structure and Function of Cytochromes," ed. by K. Okunuki, M. D. Kamen and I. Sekuzu, University of Tokyo Press, Tokyo, 1968, p 174.

24) B. Chance, J. Biol. Chem., 202, 397 (1953).

25) K. Miki, I. Sekuzu and K. Okunuki, Ann. Rep. Biol. Works, Fac. Sci., Osaka Univ., 15, 33 (1967). 